\title{
Carrying capacity estimation of Sumatran elephant habitat (Elephas maximus sumatranus T) in Tesso Nilo National Park
}

Defri Yoza • Yusni Ikhwan Siregar • Aras Mulyadi • Sujianto

D Yoza (Corresponding author)

Department of Forestry, Agricultural faculty, University of Riau, Pekanbaru, Indonesia.

email: die_rahmad@yahoo.com
YI Siregar - A Mulyadi - Sujianto

Department of Environmental Science, Graduate Program, University of Riau, Pekanbaru, Indonesia.

Received: June 10, 2019 • Accepted: August 14, 2019 - Published Online: September 30, 2019

\begin{abstract}
Forest encroachment reduces elephant habitat area while oil palm plantations and industrial plantations reduce and even cut the elephant roaming area. This study aims to estimate the carrying capacity of elephant habitat in Tesso Nilo National Park, Indonesia. Data collection on elephant populations uses direct and indirect surveys. Direct surveys are carried out by direct encounter with the elephants and counting is done at the meeting. The indirect survey was carried out in two ways, namely by counting dung and traces of elephants as well as interviews with mahout and the community. Dung calculation is done by the path method that is on the elephant roaming track. Interviews of mahout and community were conducted to find out the number of elephants passing through residential areas. Based on the results of the study, the capacity of 1 ha of Sumatran elephant feed support was 0.05 Elephants/day for the secondary forest with proper use $(\mathrm{P})$ of $60 \%$ with a growth cycle of 60 days. In the area of $1,590.18$ ha, the carrying capacity of secondary forest feed can accommodate 83.93 Elephants /day or 84 Elephants/day. One elephant in the secondary forest can be fulfilled their needs with an area of 18.95 ha or means that 1 ha of secondary forest is only able to provide 0.05 Elephants/ day. In shrubs, habitat shows that 1 ha of the shrubs can support 0.21 Elephants /day or with an area of 2,132.90 ha capable of supporting elephants as much as 447.91 Elephants/day or 448 Elephants/day. One elephant can be fulfilled with an area of 4.76 ha of bush per day. This shows that the availability of feed in 1 ha of Tesso Nilo National Park area is insufficient for 1 elephant.
\end{abstract}

Keywords: dung, feed, natural forest, shrubs

\section{Introduction}

Elephants are the mainland mammals left on the surface of the earth. These Elephants are spread in Africa with species Loxodanta africana and Asian species with the type Elephas maximus. African elephants are divided into 2 types, namely savanna elephant (Loxodonta africana africana) and forest elephant (Loxodonta africana cyclotis) (Sukumar 2003). The species Elephas maximus is also found on the island of Sumatra with a young of the type Sumatranus so that it becomes Elephas maximus sumatranus.

On Sumatra Island, Elephas maximus sumatranus became an enemy of oil palm farmers but was protected by law as a protected animal. On the one hand, these Elephants are considered pests, but on the other hand, their existence should not be disturbed by the community because they could face a prison sentence. Elephants are included as Elephants that protected by Law No.5 year 1990 concerning Conservation of Natural Resources and their Ecosystems. The elephant species was included in the list of Elephants threatened with extinction in 2004 under the IUCN Red List of Threatened Species (IUCN 2004) and listed in the Endangered Species of Wild Fauna and Flora (UNEP-WCMC 2003).

Sumatran elephants are spread from the northern tip of Sumatra (Aceh) to the south of Sumatra (Lampung) with fragmented habitat conditions (Soehartono et al 2007). The elephant habitat was divided because of the width population settlement in 1970-1980 with the transmigration program. In 1990 until now there was a massive forest clearing for oil palm plantations and industrial plantations, which damaged the habitat of Sumatran elephants.

The location of the elephant habitat has been replaced by settlements, roads, oil palm plantations, and industrial plantations. The elephant habitat is no longer able to support the life of elephants in terms of both food, water, rest areas, and roaming areas.

This phenomenon is also found around and within the Tesso Nilo National Park area surrounded by oil palm plantations, industrial plantations and forest encroachment. These various activities also reduce the carrying capacity of elephant habitat. Forest encroachment reduces elephant habitat area while oil palm plantations and industrial plantations reduce and even cut the elephant roaming area. 
This study aims to analyze changes in the carrying capacity of elephant habitat in the Tesso Nilo National Park.

\section{Materials and Methods}

This research was conducted in January-June 2017 in Tesso Nilo National Park (TNNP), Indonesia especially in elephant habitat consisting of secondary forests and shrubs.
Tesso Nilo National Park is located at Pelalawan District, Riau Province of Indonesia, geographically at $0^{\circ} 08^{\prime} 8,6^{\prime \prime}$ north latitude $-0^{\circ} 21^{\prime} 15,2^{\prime \prime}$ south latitude and $101^{\circ} 03^{\prime} 20,7^{\prime \prime}$ east longitude $-101^{\circ} 51^{\prime} 43,6^{\prime \prime}$ east longitude. Determination of the location of the study purposively at locations that become elephant roaming, especially those with secondary forests and shrub bushes. Research location shown in Figure 1.

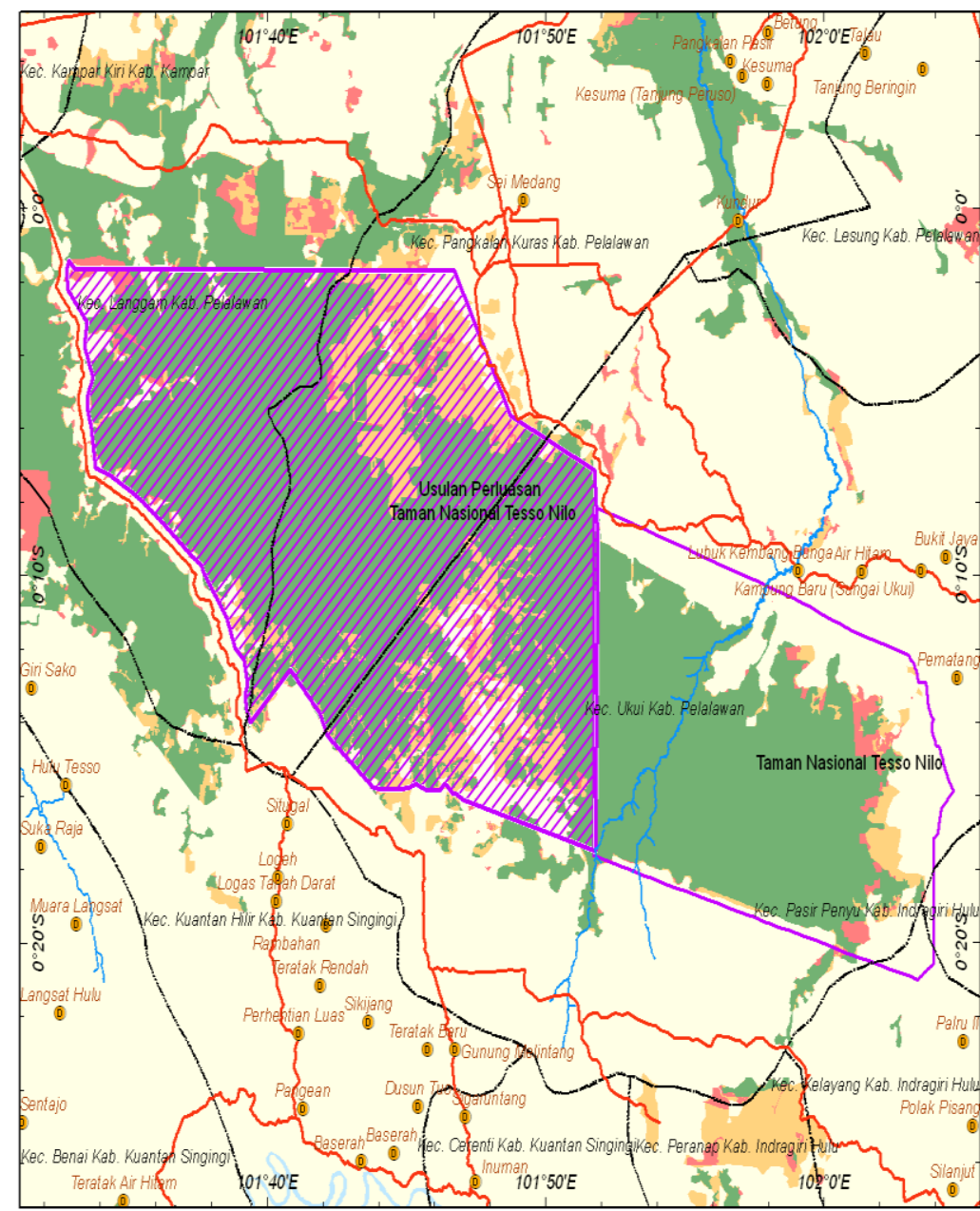

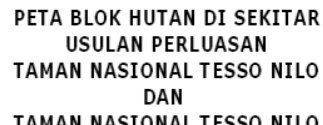

TAMAN NASIONAL TESSO NILO

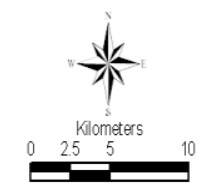

Legenda

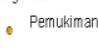

Sungai

- Jalan

?7. Batas Kecamatan

$\square$ Existing Taman Nasional Tesso Nilo (38.576 Ha)

Usulan Pertuasan TNTN berdasarkan rekomendasi

- Tutupan hutan alam 2007

- Tutupan hutan alam 2006 yang hilang

Tutupan hutan alam 2005 yang hilang

Sumber data:

1. Tamanan Nasional Tesso Nib
Oishut Riau \& Menteri Kehutanan 2004

Usulan Perluasan:

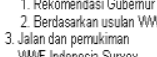

WWF Indonesia Surrey
4. Tutupan hutan alam 2005, 2006, 2007

Tutupan hutan alam 2005, 2006, 2007 ,
WWWF Indonesia Intiepretasi Citra Satelite

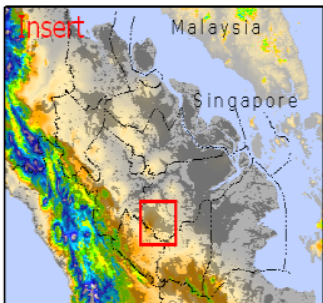

Figure 1 Research Location at TNNP (Tesso Nilo National Park).

\section{Data collection}

The type of data collected in this study consists of primary data and secondary data. Primary data collected consisted of elephant population data, elephant habitat area, and elephant habitat productivity. Secondary data collected consisted of data on carrying capacity of elephant habitat in recent years at the TNNP location and the general condition of the TNNP location.

\section{Elephant population}

Data collection on elephant populations uses direct and indirect surveys. Direct surveys are carried out by encounter elephants directly and counting is done at the meeting. The indirect survey was carried out in two ways, namely by counting dung and traces of elephants as well as interviews with mahout and the community. Dung calculation is done by the track method that is on the elephant-roaming track. Interviews of mahout and community were conducted to find out the number of elephants passing through residential areas. From the results of dung calculations, traces and interviews with mahout and the community can be calculated elephant population density.

The density of elephant population based on dung according to Barnes (2001) can be approached through 3 (three) variables, i) abundance/amount of dung per $\mathrm{km}^{2}$, ii) the rate of dung production per day and iii) the decomposition rate of dung (days). The amount of dung is the accumulation of all dung piles found along the observation transect per $\mathrm{km} 2$. The rate of dung production (defecation rate) is how many times 
an elephant poops per day, which according to Santiapillai and Suprahman (1986) ranges from 16-18 times per day and based on the standards of CITES in Lahkar (2007) is 18.07 per day. The decomposition rate of dung shows how long (days) the dung piles decomposes, by observing the sample of dung hat have been marked (Lahkar 2007). Dung asunder Rate uses a value of 0.0071 (Rizwar et al 2001).

\section{Elephant feed production}

Data collection on elephant feed production was carried out by analyzing vegetation on two elephant habitat locations, namely shrubs and secondary forests. Production data were collected by two ways of analyzing vegetation on both elephant habitat and cutting elephant feed to determine the weight of the elephant's biomass feed.

Elephant feed production is quantified by cutting feed plants for seedling level, sapling level, understorey (including grass), shrubs, lianas, epiphytes, palms, and pandanus; then weighed to get the wet weight. The size of the plot of observation samples for grass types (including reeds) is $1 \mathrm{~m} \mathrm{x}$ $1 \mathrm{~m}$, while for seedlings, understorey (other than grass) shrubs/herbs, ferns, with a sample size of $2 \mathrm{~m} \times 2 \mathrm{~m}$. For saplings, lianas, palms, and pandanus (with $5 \mathrm{~cm}<\mathrm{DBH} \leq 10$ $\mathrm{cm}$ ); example plot size is $5 \mathrm{mx} 5 \mathrm{~m}$ (Solichin, 2009). Placement of sample plots is chosen based on observations on the location of feed sources, with the number of sample plots adapted to field conditions.

\section{Estimated carrying capacity of elephant habitats}

Data on the estimated carrying capacity of elephant habitat are collected by a combination of primary data and secondary data. Primary data carrying capacity was calculated from the amount of elephant feed production, elephant population, and elephant habitat area while secondary data carrying capacity was obtained from data and information on research related to the carrying capacity of elephant habitat in the Tesso Nilo National Park (TNNP).

\section{Data analysis}

Data analysis of elephant population was processed using the dung count approach. The dung count approach uses the approach of the amount of dung multiplied by the discharge rate of the dung divided by the rate of waste production. Vegetation analysis data is processed using the important value index (IVI). The important value index of each type of tree includes the sum of the Relative Density (RD), Relative Frequency (RF) and Relative Domination (RD). Important Value Index (IVI) is a quantitative parameter that can be used to express the level of dominance (level of mastery) of species in a plant community (Soegianto, 1994).

The carrying capacity of elephant habitat is processed using the equations of elephant feed production at an elephant habitat location. According to Alikodra (1990), based on the results of the weighing of wet weight obtained from each sample plot/path, biomass can be estimated using the formula for the amount of biomass in an area divided by the width of the track. This calculation is based on the assumption that the feed needs of elephants per 200-300 kg /Elephants/day (Ramono 2001) and with the precautionary principle are determined to be $300 \mathrm{~kg} /$ Elephants/day. According to Abdullah (2002), the habitat carrying capacity is calculated by comparing the area of 1 ha of the area with the carrying capacity of feed where the carrying capacity of feed is approached with the formula of total biomass divided by the needs of elephants per Elephants per day

\section{Result and Discussion}

\section{Elephant population}

From the results of observations on elephant populations in elephant habitat with a path area of 2 ha, the following results can be seen in Table 1 .

Calculation of elephant population can be known by the discovery of traces and dung. This discovery is based on elephant legacy signs, including elephant footprints, former food fragments of elephants and elephant dung, which are commonly found around creeks such as the Perbakalan River and Air Sawan River. Population counting is based on the calculation of elephant dung found on elephant population observation pathways.

In Table 1 it can be seen that the presence of the most elephants is in restoration camp areas which are natural forest areas and rarely occur in human activities. The restoration campsite is an area of natural forest which still has sufficient diversity and quantity of feed. At this location, it can be said that the area still has a carrying capacity of habitat that is still good for the Sumatran elephant population, so the population in that area is quite width.

Table 1 Number of populations in various locations.

\begin{tabular}{llc}
\hline $\mathrm{N}^{\circ}$ & Location & Total population \\
\hline 1 & Post of Lancang Kuning TNNP & 11 \\
2 & Around Lubuk Kembang Bunga Village & 2 \\
3 & Shrubs of TNNP & 17 \\
4 & Secondary forest TNNP (Restoration Camp) & 19 \\
& Total & 49 \\
\hline
\end{tabular}


The smallest population is in the vicinity of the Lubuk Kembang Bunga Village which is a rural area and on average is a community oil palm plantation area. In this area, there are many human activities so that elephants tend to avoid humans. Carrying capacity at this location can also be said to be low because the area is dominated by oil palm residents and there are not many shrubs and trees which usually become feed and shelter for elephants.

In the area of Lancang Kuning and shrubs, the population has a higher population than Lubuk Kembang Bunga Village. In this location, it is predominantly dominated by shrubs and acacia which can become feed and shelter for elephants. The close distance between the edge and natural forest and locations that tend to be infrequently entered by humans makes elephants tend to be many in this location.

Researches related to the size of the elephant population found at the Tesso Nilo National Park can be seen in Table 2.

Based on Yoza and Sari (2008) it is known that in an area of 1331.19 ha one pocket of elephants was found consisting of 3 small groups namely 2 groups in Lubuk Kembang Bunga Village and 1 group at the Camp location. Lancang Kuning. Each group of elephants was found in secondary forests and shrubs where the number of elephants found in group 1 was 8 Elephants, group 2 were 5 Elephants and group 3 were 5 Elephants. The total number of elephants in the three small groups is 18 .

Table 2 Number of elephants in Tesso Nilo Elephant Pocked.

\begin{tabular}{|c|c|c|c|c|}
\hline $\mathrm{N}^{\circ}$ & Researcher & Total Population & Number of individuals & Remarks \\
\hline 1 & Yoza and Sari (2008) & 1 population & 18 Elephants & $\begin{array}{l}\text { Lubuk Kembang Bungo } \\
\text { Village and Lancang } \\
\text { Kuning Camp }\end{array}$ \\
\hline 2 & $\begin{array}{l}\text { Desay and Syamsuardi } \\
\text { (2009) }\end{array}$ & 3 population (total 118 ) or 200 & $\begin{array}{l}\text { \# } 58 \text { Elephants } \\
\text { \# 35 Elephants } \\
\text { \# } 25 \text { Elephants }\end{array}$ & $\begin{array}{l}\text { Ukui-Nilo } \\
\text { Rantau Kasih Tesso }\end{array}$ \\
\hline 3 & Yoza (2017) & 1 population & 38 Elephants & $\begin{array}{l}\text { Lubuk Kembang Bungo } \\
\text { Village }\end{array}$ \\
\hline 4 & WWF (2017) & 2 population & 150-180 Elephants & North and southeast Tesso \\
\hline 5 & BTNTN (2017) & 3 population & 88 Elephants & $\begin{array}{l}\text { North, South and Rantau } \\
\text { Kasih }\end{array}$ \\
\hline
\end{tabular}

Each population found by researchers has a difference in number. This is influenced by direct and indirect methods. The method directly uses encounters while the indirect method uses the trace and dung approach. The method of calculating population based on traces and dung has a bias because it is related to the amount of dung released by elephants.

Based on these calculations the population used was 180 elephants because the number closest to the actual population was based on the DNA method carried out by WWF (2017) in collaboration with the Eijkman Institute in Germany. In addition, a survey conducted by WWF (2017) with the number 180 approached the amount calculated by Desai and Syamsuardi (2009) with a population of 118 individuals or 200 individuals.

\section{Type and amount of elephant feed}

Elephant feed production is approached by calculating the number of species that become elephant feed in Tesso Nilo National Park and the important value index of vegetation. The important value index in the location of elephant habitat can be seen in Table 3 .

Based on Table 3, it can be seen that the growth rate in secondary forests was found starting from the seedling, sapling, pole and tree levels, while the bushes were found from the seedling, sapling and pole levels. In shrubs, there was no tree growth rate found and at the pole level only 1 type of pole was found, Acacia mangium. Secondary forests are dominated by tree species, while shrubs are dominated by understorey species and pioneer tree species such as mahang and acacia are found. The highest number of individuals is found in the seedling level in secondary forests and shrubs where the highest number of elephant food is found at this level. In addition to elephant grasses also like plants at the stake, pole, and tree level (Sukumar 1989). The observations at the observation site, elephants also eat leaves at the stake level, for example, species in the family Euphorbiaceae, while for plants on the pole level part of the bark is a favorite part, for example, the type Dillenia axcelsa, Mallotus paniculatus.

\section{Sumatran elephant feed production}

Elephants choose certain parts that are preferred on a type of plant because not all parts of the types of food plants are eaten by elephants. Plant parts which are feed for elephants include leaves, stems, fruit, bark, roots, and tubers. The type of grass is almost all parts that grow above the ground are eaten by elephants. 
Table 3 Important value of vegetation type and amount of elephant feed type.

\begin{tabular}{|c|c|c|c|c|c|c|}
\hline $\mathrm{N}^{\mathrm{o}}$ & Location & Growth rate & Species & $\begin{array}{l}\text { Important } \\
\text { value }(\%)\end{array}$ & $\begin{array}{l}\text { Total } \\
\text { (N/ha) }\end{array}$ & $\begin{array}{l}\text { Amount of elephants } \\
\text { feed type }(\mathrm{N})\end{array}$ \\
\hline \multirow[t]{12}{*}{1} & \multirow{12}{*}{$\begin{array}{l}\text { Secondary } \\
\text { forest }\end{array}$} & \multirow[t]{3}{*}{ Seedling } & Eugenia odorata & 27,50 & \multirow[t]{3}{*}{26700} & \multirow[t]{3}{*}{17} \\
\hline & & & Callophyllum sp & 20,46 & & \\
\hline & & & Syzygium sp & 20,01 & & \\
\hline & & \multirow[t]{3}{*}{ Stake } & Eugenia odorata & 23,99 & \multirow[t]{3}{*}{2064} & \multirow[t]{3}{*}{17} \\
\hline & & & Eugenia ridleyi & 18,31 & & \\
\hline & & & Garcinia xantochymus & 8,38 & & \\
\hline & & \multirow[t]{3}{*}{ Pole } & Eugenia ridleyi & 23,85 & \multirow[t]{3}{*}{142} & \multirow[t]{3}{*}{4} \\
\hline & & & Shorea parvifolia & 23,85 & & \\
\hline & & & Litsea $s p$ & 23,53 & & \\
\hline & & \multirow[t]{3}{*}{ Tree } & Stemonorus scorpioides Bacc. & 21,23 & \multirow[t]{3}{*}{125} & \multirow[t]{3}{*}{7} \\
\hline & & & Pentaspadon motleyii & 19,58 & & \\
\hline & & & Shorea parvifolia & 15,82 & & \\
\hline \multirow[t]{8}{*}{2} & \multirow[t]{8}{*}{ Shrubs } & \multirow[t]{3}{*}{ Seedling } & Gleichenia trackaris & 49,39 & \multirow[t]{3}{*}{136500} & \multirow[t]{3}{*}{19} \\
\hline & & & Alshophila cuspidata & 19,79 & & \\
\hline & & & Stenochlaena palustris & 15,54 & & \\
\hline & & \multirow[t]{3}{*}{ Stake } & Macaranga triloba & 30,83 & \multirow[t]{3}{*}{2224} & \multirow[t]{3}{*}{9} \\
\hline & & & Acacia mangium & 25,53 & & \\
\hline & & & Macaranga gigantea & 20,24 & & \\
\hline & & Pole & Acacia mangium & 100 & 4 & 1 \\
\hline & & Tree & not found & 0 & 0 & 0 \\
\hline
\end{tabular}

The shrubs track

The calculation of elephant feed production in the study carried out on shrubs consisted of 12 sample plots, from each plot there will be known the amount of biomass from various types of plants in the plot. Data obtained from the calculation of biomass in each plot can be seen in Table 4 .

From Table 4 its can be seen that plot 5 has the highest total biomass of $1.37 \mathrm{~kg} / \mathrm{m} 2$. This plot consists of the planted teki grass, needlegrass (Chrysopogan aciculata), wiregrass (Panicum repens) and sianik (Cyperus aromaticum). The second most biomass is found in plot 11 which consists of field teki grass (Cyperus rotundus), teki grass (Cyperus $s p$ ), and wiregrass (Panicum repens). The third most biomass is found in plot 12 which consists of field teki grass (Cyperus rotundus), needlegrass (Chrysopogan aciculata), wiregrass (Panicum repens) and sianik (Cyperus aromaticum). The results of the calculation of fresh elephant biomass on the shrubs observation track were 12 plots of $7.56 \mathrm{~kg}$. If the results are calculated for an area of 1 ha, then the amount of biomass is $6,300 \mathrm{~kg} / \mathrm{ha}$.

Table 4 Calculation of elephant feed biomass based on plots.

\begin{tabular}{ccccc}
\hline $\mathrm{N}^{\circ}$ & $\mathrm{N}^{\text {Plot }}$ & Biomass $(\mathrm{Kg})$ & Width $\left(\mathrm{m}^{2}\right)$ & Total Biomass $\left(\mathrm{Kg} / \mathrm{m}^{2}\right)$ \\
\hline 1 & Plot 1 & 0,39 & 1 & 0,39 \\
2 & Plot 2 & 0,52 & 1 & 0,52 \\
3 & Plot 3 & 0,65 & 1 & 0,65 \\
4 & Plot 4 & 0,39 & 1 & 0,39 \\
5 & Plot 5 & 1,37 & 1 & 1,37 \\
6 & Plot 6 & 0,56 & 1 & 0,56 \\
7 & Plot 7 & 0,70 & 1 & 0,70 \\
8 & Plot 8 & 0,55 & 1 & 0,55 \\
9 & Plot 9 & 0,70 & 1 & 0,70 \\
10 & Plot 10 & 0,17 & 1 & 0,17 \\
11 & Plot 11 & 0,81 & 1 & 0,81 \\
12 & Plot 12 & 0,75 & 1 & 0,75 \\
& & Total & 12 & 7,56 \\
\hline
\end{tabular}


Based on observations, it is shown that the types of biomass calculated are the types of plants eaten by elephants. These types are included in the family Cyperacea and Poaceae. These types are liked by elephants. The types that are liked by elephants usually correlate with the needs of elephants for the nutritional value contained in these foods. This is in track with Zahrah (2002) and Supartono (2007) who found that elephants in East Aceh and Kerinci Seblat also like plant species from the families Cyperaceae and Poaceae.

\section{Secondary forest track}

Calculation of elephant feed production in subsequent studies was carried out in secondary forests. Data obtained from the calculation of biomass in each plot can be seen in Table 5.

Table 5 Calculation of elephants feed biomass based on plots

\begin{tabular}{|c|c|c|c|c|}
\hline $\mathrm{N}^{\mathrm{o}}$ & $\mathrm{N}^{\mathrm{o}}$ Plot & Biomass (Kg) & Width $\left(\mathrm{m}^{2}\right)$ & Total Biomass $\left(\mathrm{Kg} / \mathrm{m}^{2}\right)$ \\
\hline 1 & Plot 1 & 0,11 & 1 & 0,11 \\
\hline 2 & Plot 2 & 0,21 & 1 & 0,21 \\
\hline 3 & Plot 3 & 0,19 & 1 & 0,19 \\
\hline 4 & Plot 4 & 0,10 & 1 & 0,10 \\
\hline 5 & Plot 5 & 0,41 & 1 & 0,41 \\
\hline 6 & Plot 6 & 0,24 & 1 & 0,24 \\
\hline 7 & Plot 7 & 0,08 & 1 & 0,08 \\
\hline 8 & Plot 8 & 0,10 & 1 & 0,10 \\
\hline 9 & Plot 9 & 0,09 & 1 & 0,09 \\
\hline 10 & Plot 10 & 0,17 & 1 & 0,17 \\
\hline 11 & Plot 11 & 0,09 & 1 & 0,09 \\
\hline \multirow[t]{2}{*}{12} & Plot 12 & 0,11 & 1 & 0,11 \\
\hline & & Total & 12 & 1,90 \\
\hline
\end{tabular}

From Table 5 its can be seen that plot 5 has the highest total fresh biomass, which is $0.41 \mathrm{~kg} / \mathrm{m} 2$, which consists of hedges (Ixonanthes icosandra), stone wood (Irvingia malayana) and kandis (Garcinia xantochymus). The second highest fresh biomass is found in plot 6 as much as 0.24 $\mathrm{kg} / \mathrm{m} 2$, which consists of tenggek burung, kelat merah (Eugenia ridleyi), setunduk, caku, kelat putih (Eugenia odorata), kayu tuntubung and antui (Mezzetia leptopoda). The third highest fresh biomass is found in plot 2 of $0.21 \mathrm{~kg} / \mathrm{m} 2$, which consists of kelumpang (Sterculia foetida) and antui (Mezzetia leptopoda).

The results of the calculation of fresh feed elephant biomass on the secondary forest observation track were 12 plots of $1.90 \mathrm{~kg}$. If the results are calculated for an area of 1 ha, then the amount of biomass is $1,583.33 \mathrm{~kg} / \mathrm{ha}$. In the secondary forest observation track, many tree species are found at the seedling level. These types are eaten by elephants in all parts. In addition to the seedlings, there are also types of herbs eaten by elephants. This is in accordance with Zahrah (2002) and Supartono (2007) which states that elephants in East Aceh and Kerinci Seblat also like types of food from seedling and herbaceous levels.

Estimation of carrying capacity of sumatran elephant feed
Based on the results of the calculation of the carrying capacity of elephants in TNNP on the shrubs and secondary forests, the following results can be seen in Table 6 .

Based on the results of the study, the capacity of 1 ha of Sumatran elephant feed support was 0.05 Elephants /day for the secondary forest with proper use $(\mathrm{P})$ of $60 \%$ with a growth cycle of 60 days. Proper use value is used for topography that is not suitable for elephants. In the area of 1590.18 ha, the carrying capacity of secondary forest feed can accommodate 83.93 Elephants/day or 84 Elephants/day. One elephant in the secondary forest can be fulfilled their needs with an area of 18.95 ha or means that 1 ha of secondary forest is only able to provide 0.05 Elephants/day. The carrying capacity of the environment has an understanding of the ability of the environment to support the lives of humans and other living things.

Likewise with shrubs which show that 1 ha of the shrubs can support 0.21 Elephants /day or with an area of $2,132.90$ ha capable of supporting elephants as much as 447.91 Elephants/day or 448 Elephants /day. One elephant can be fulfilled with an area of 4.76 ha of shrubs per day. This shows that the availability of feed in 1 ha of Tesso Nilo National Park area is insufficient for 1 elephant. As a result, elephants will find new locations and eat community plants to meet the needs of feed in width quantities. This result is not 
much different from the research of Sugiyanto (2017) at the Air Hitam TNNP resort.

Based on the research of Sugiyanto et al (2017) states that in shrubs habitats with a total area of 3,534 ha obtained forage weight of elephant feed for $13,580,657.14 \mathrm{~kg}$, the carrying capacity of elephant feed is $27,161.31$ Elephants/day. If the plant life cycle found in shrub habitat is 60 days, it can accommodate 452 elephants. In natural forest habitats with a total area of 4,860 ha obtained forage weight of elephant feed for $1,940,528.57 \mathrm{~kg}$, the carrying capacity of elephant feed is 3,881.06 Elephants/day. If the life cycle of plants found in natural forest habitat is 60 days, the elephant can accommodate as many as 64 elephants.

Table 6 Estimation of carrying capacity of sumatran elephant feed in lubuk kembang bunga village.

\begin{tabular}{ccccccc}
\hline Width (ha) & $\begin{array}{c}\text { Total biomass } \\
(\mathrm{kg})\end{array}$ & $\begin{array}{c}\text { Elephants feed needs } \\
\text { (kg/Elephants/day) }\end{array}$ & $\begin{array}{c}\text { Proper use } \\
(60 \%)\end{array}$ & $\begin{array}{c}\text { Cycle } \\
60 \text { day }\end{array}$ & $\begin{array}{c}\text { Feed carrying capacity } \\
\text { (Elephants/day) }\end{array}$ & Remarks \\
\hline 1 & $1.583,33$ & 300 & 0,6 & 60 & 0,05 & $\begin{array}{c}\text { Secondary } \\
\text { forest } \\
\text { Secondary } \\
\text { forest }\end{array}$ \\
$1.590,18$ & 2.517 .785 & 300 & 0,6 & 60 & 83,93 & 0,21 \\
$2.132,90$ & 13.437 .270 & 300 & 0,6 & 60 & 447,91 & Shrubs \\
\hline
\end{tabular}

The study results of Yoza and Sari (2008) estimated that habitat carrying capacity for 1 elephant was 16.67 ha/elephants/day. While the number of wild elephants in the research location (Lubuk Kembang Bunga Village) is estimated at 18 . This can be seen from the trail left in the form of dung, footprints and former food fragments of elephants. With the total number of elephants found, the carrying capacity of the habitat is 300.06 ha /Elephants /day. This shows that with an area of $1,331.19$ ha it can still accommodate elephants in width numbers without considering other factors.

Based on the calculation of the number of elephants at the study site, it was estimated that there were 180 Elephants. This amount can still be accommodated by elephant habitat in the TNNP area with the amount that can be accommodated by shrubs and secondary forests as much as 532 Elephants/day. But the elephants inside the TNNP area are still out of the area to look for food. This is thought to be caused by 1) feed calculated in the area which is outside the elephant roaming track or not passed by the elephant, 2) the feed is found in areas that are not economically traversed by elephants, 3 ) the elephant's feed is far from the water source, 4) the feed of the elephant is not safe for consumption either close to humans (forest encroachers) or close to predators (tigers). These reasons caused elephants to leave the TNNP area to find food on plantations or community settlements.

The needs of elephants in the TNNP area can be fulfilled by planting elephant feed plants at locations in open land or areas covered by acacia. Requirements that can be used as the basis for selecting planting locations consist of 1) feed planted on the elephant roaming track or on the path passed by the elephant, 2) the feed is found in economically traversed elephants, 3) the elephant's feed is close to water sources or location salt, 4) elephant feed is safe for consumption both far from humans (forest encroachers) or far from predators (tigers). Locations far from humans by moving humans from inside the TNNP area or away from predators or away from primary forests.

\section{Conclusions}

Based on the results of the study, the capacity of 1 ha of Sumatran elephant feed support was 0.05 Elephants/day for the secondary forest and the carrying capacity of $1.590,18$ ha can accommodate 84 Elephants /day. Likewise with shrubs which show that 1 ha of the shrubs can support 0.21 Elephants/day or with an area of 2,132.90 ha capable of supporting elephants as much as 448 Elephants/day. This shows that the availability of feed in 1 ha of Tesso Nilo National Park area is insufficient for 1 elephant and fluctuated every year.

\section{Acknowledgments}

Acknowledgments are expressed to the Tesso Nilo National Park Office Elephants and staff who have helped carry out this research, to the Tesso Nilo Foundation, which facilitated the conduct of this research along with the mahout who had accompanied the field.

\section{Conflict of Interest Statement}

We confirm that we have no conflicts of interest.

\section{References}

Alikodra HS (1990) Management of Wild Life Vol. 1. Center for Inter-University Life Sciences. Bogor: Bogor Agricultural Institute.

Abdullah (2002) Carrying Capacity Estimation of Sumatran Elephant Habitats (Elephas maximus sumatranus Temminck) in the Tesso Nilo Riau Forest Area. (Thesis). Department of Biology, Major of 
Ecology. Faculty of Math and Science. Bandung: Bandung Institute of Technology.

Barnes RFW (2001) How reliable are counts for estimating elephant numbers? African Journal of Ecology 39:1-9.

Tesso Nilo National Park Office. Tesso Nilo National Park Management Plan (2005-2025).

Desai A, Syamsuardi (2009) Status of Elephants In Riau Province, Sumatra WWF Indonesia.

IUCN - The World Conservation Union (2004) IUCN Red List of Threatened Species. Accessed on February 16, 2014).

Lahkar (2007) An assessment of human elephant conflict in Manas National Park, Assam, India.

Ramono WS (2001) Sumatran Elephants and their Problems. In Proceedings of the Sumatran Elephant Conservation Workshop. April 24-25 2000. Cisarua. Bogor.

Rizwar D, Zulfian (2001) Population Density and Elephant Habitat Conditions Elephas maximus sumatranus in Forest Fragmentation Around the Kerinci Seblat National Park Area, North Bengkulu Regency.

Santiapillai C, Suprahman H (1986) The Ecology of the Elephant (Elephas maximus L.) in the Way Kambas Game Reserve, Sumatra. Unpublished report, WWF / IUCN Project 3133, WWF, Indonesia.

Soegianto A (1994) Quantitative Ecology: Population and Community Analysis Methods. National Business Publisher. Jakarta.

Soehartono T, Susilo HD, Sitompul AF, Gunaryadi D, Purastuti EM, Azmi W, Fadhli N, Stremme C (2007) The Strategic and Action Plan for Sumatran and Kalimantan elephant. Ministry of Forestry, Jakarta. Indonesia.

Solichin (2009) Guide to the Forest Carobon Inventory: Case study in the peat swamp forest of Merang, South Sumatra. Merang REDD Pilot Project-GIZ. Palembang.
Sugiyanto EEL, Erianto, Prayogo H (2017) Availability of Feed of Sumatran Elephants (Elephas Maximus Sumatranus Temminck, 1847) At Air Hitam Resort Tesso Nilo National Park Pelalawan District, Riau Province. Journal of Sustainable Forests 5:147-155.

Sukumar R (1989) The Asian Elephant Ecology and Management. Cambridge University Press.

Sukumar R (2003) The Living Elephants: Evolutionary Ecology, Behavior and Conservation. Oxford University Press, USA.

Supartono (2007) Preference and Estimation of Natural Feed Productivity Population of Sumatran Elephants (Elephas maximus sumatranus Temmick, 1847) in the Seblat Elephant Training Center (PLG) of North Bengkulu. IPB Graduate School Thesis.

Syarifuddin H (2008) Carrying Capacity Analysis of Habitat and Dynamics Modeling of Sumatran Elephants: A Case Study in the Seblat Region of North Bengkulu Regency. (Dissertation). Bogor (ID): Bogor Agricultural University.

UNEP-WCMC (2003) UNEP-WCMC Species Database: CITESListed Species on the World Wide Accessed on April 20, 2013.

World Wildlife Fund/WWF (2017) Number of Elephants in Tesso Nilo National Park.

Yoza, D, Sari I (2008) Carrying Capacity Estimation of Sumatran Elephant Habitats (Elephas maximus sumatranus Temminck, 1847) Based on Feed Availability in Pelalawan Resort Tesso Nilo National Park. Research Report.

Zahrah M (2002) Community Characteristics Analysis of Habitats Vegetation of Sumatran Elephant (Elephas maximus sumatranus) in East Aceh District Forest Areas and Langkat District. IPB Graduate Program Thesis. Not published. 